\title{
Nutrient flows in lowland dairy farms in the Italian Alps
}

\author{
Monica Bassanino, ${ }^{1}$ Dario Sacco, ${ }^{1}$ Annalisa Curtaz, ${ }^{2}$ Mauro Bassignana, ${ }^{2}$ Carlo Grignani ${ }^{1}$ \\ ${ }^{1}$ Dipartimento di Agronomia, Selvicoltura e Gestione del Territorio, Università di Torino, \\ Grugliasco; \\ ${ }^{2}$ Institut Agricole Régional, Région La Rochère, Aosta, Italy
}

\begin{abstract}
A traditional dairy production system is still common today in the mountain environment of the Italian Alps, enhancing the economic valorisation of milk through the production of quality cheese such as Fontina PDO (Protected Designation of Origin), and favouring the agroenvironmental management of marginal areas. This type of dairy system depends mainly on summer grazing: farmers set up the farm stock on the basis of the high-altitude grassland areas available. For the rest of the year, the livestock is housed on the farm lowland, consequently reaching high stocking rates. Since grassland areas are limited in size here, animal feeding is largely based on acquired forages. In order to study the environmental sustainability of the lowland farm areas, agronomic management, nitrogen $(\mathrm{N})$ and phosphorus (P) farm-gate balances were calculated for 22 livestock farms in the Valle d'Aosta region. Lowland surfaces show a quite high variability, with an average value of 6.8 ha. An unbalanced stocking rate referred to the lowland is common showing an average value of 5.7 livestock units (LU) ha ${ }^{-1}$, but reaching a maximum of $26.8 \mathrm{LU} \mathrm{ha}^{-1}$. Lowland milk production is approximately $1700 \mathrm{~kg}$ per LU per year, but some farms could reach $3500 \mathrm{~kg}$ per LU The feed efficiency varies from 1.1 to $4.7 \mathrm{~kg}$ milk per $\mathrm{kg}$ feed, depending on the farm feeding strategy. The average $\mathrm{N}$ farm-gate balance is equal to $75 \mathrm{~kg} \mathrm{~N} \mathrm{ha}^{-1}$. The two main input components are represented by purchased hay and feed, both showing the highest variability between farms. The output data also differ substantially among farms. The manure sold is the most important output component and represents $70 \%$ of the total output on average. The P farm gate balance surplus is
\end{abstract}

\footnotetext{
Correspondence: Dario Sacco, Dipartimento di Agronomia, Selvicoltura e Gestione del Territorio, Università di Torino, via Leonardo da Vinci 44, 10095 Grugliasco, Italy.

Tel. +39.011 .6708787 - Fax: +39.011 .6708798 .

E-mail: dario.sacco@unito.it

Key words: dairy farm, farm-gate nutrient balance, mountain environment, nitrogen, organic fertilization, phosphorus, territorial scale.

Funding: paper presented at the SIA Congress 2010.

Received for publication: 21 July 2011.

Accepted for publication: 10 September 2011.

CC Copyright M. Bassanino et al., 2011

Licensee PAGEPress, Italy

Italian Journal of Agronomy 2011; 6:e28

doi:10.4081/ija.2011.e28

This work is licensed under a Creative Commons Attribution NonCommercial 3.0 License (CC BY-NC 3.0).
}

equal to $6 \mathrm{~kg} \mathrm{ha}^{-1}$, but more than $25 \%$ of the farms considered show a negative value. The surpluses calculated in this work can be compared with the values belonging to a distribution calculated for bovine farms under different management and environmental conditions in Italy and Europe. They occupy the lower part of the distribution and are similar to those measured in mountains or other extensive environments.

\section{Introduction}

Traditional dairy production systems are still common today in the Italian Alps. In the limiting agro-environment of Valle d'Aosta, a livestock system based on permanent grassland allows for both a good economic valorisation of milk, and the persistence of a territorial agro-environmental management. This kind of dairy system, heavily dependent on summer grazing, has three great advantages: i) it contrasts hydrogeologic degradation; ii) it stems the decline in agricultural activities, typical in many European marginal areas; iii) it produces Fontina PD0 (Protected Designation of Origin) high quality cheese. Therefore, farmers tend to set up their farm stock on the basis of the high-altitude grassland areas available in summer. During the other seasons, the stock is housed in the lowlands and animal feeding is largely based on acquired forages. Alpine pastures are greatly prone to agro-environmental problems such as soil erosion, nutrient depletion, overgrazing or, on the other hand, abandonment and shrub invasion, as many authors have already reported (Cavallero et al., 1997; Jewell et al., 2007). Less common are studies based on the environmental effects of the agronomic management of the lowland farm areas: the stocking rate can be very high here, and small grassland areas receive all the farm manure produced during the lowland period. Moreover, the animal feeding must rely on large amounts of acquired forages. Fontainemore, a municipality in Valle d'Aosta, was chosen for this study as its economy still relies mainly on agriculture largely based on alpine pastures. As limited lowland grasslands are available, the stocking rate on the lowland area is consequently quite high. This study will therefore: i) calculate the nutrient fluxes at a farm-gate level for all the farms in the municipality, considering only the lowland period; ii) analyze the main management problems that cause environmental problems and suggest possible solutions both for individual farms and on a territorial scale.

\section{Materials and Methods}

\section{The agro-environment}

The study was carried out in 2007 in Valle d'Aosta (Northwest Italy), a mountain region between $45^{\circ} 00^{\prime}$ and $45^{\circ} 50^{\prime} \mathrm{N}$ and $8^{\circ} 00^{\prime}$ and $8^{\circ} 50^{\prime} \mathrm{E}$. The climate is temperate sub-continental, strongly influenced by the orography and characterized by two main rainy periods in spring (April 
- May) and autumn (September - November), with an annual mean precipitation in Fontainemore of $1100 \mathrm{~mm}$ and an annual mean temperature of $6.8^{\circ} \mathrm{C}$ (Mercalli et al., 2003) (Figure 1). However, meteorological parameters closely depend on the altitude: as elevation increases, rainfall increases while mean temperature decreases.

Soils are usually sandy, acid, with a high percentage of organic carbon (C), slow mineralization, very low nitrogen $(\mathrm{N})$ and potassium $(\mathrm{K})$ (Freppaz et al., 2005); some of these characteristics are influenced by the soil management, mainly through meadows. According to ISTAT (2000), agriculture only covers $21.8 \%$ of the total regional surface (Table 1 ). This is due to a limiting environment with regard to climatic and topographic conditions (the mean elevation of the region is about $2100 \mathrm{~m}$ a.s.l.). The cropland is cultivated mainly with permanent meadows and pastures $(99,6 \%$ of the agricultural land); small areas have fruit trees and vineyards. Grass is mainly used for grazing; in lowland areas, where mechanical management is often possible, grass is cut for hay production (2 to 3 cuttings a year), usually followed by autumn grazing. As extensive agronomic management is implemented (Roumet et al., 1999), mineral fertilization and weed control are not adopted. Approximately 36,000 head of cattle (mainly Aosta Red Pied dairy cows) and 7500 sheep and goats are bred (AREV, 2009) in Valle d'Aosta. The animals are kept in lowland facilities during the winter; they first graze on mountain pastures (around $1000 \mathrm{~m}$ a.s.l.) in spring, and then spend the whole summer on sub-alpine and alpine pastures (up to $2500 \mathrm{~m}$ ), before returning to the lowland again. The milk produced (4000 kg per cow on average, 48,000 $\mathrm{t}$ per year) is usually made into cheese, especially Fontina PD0, both by single farmers and local cooperatives (Mantovani et al., 2003; Francesia et al., 2007). This agro-food system yields over $77 \%$ of the entire regional agricultural economic market (Trione, 2005).

\section{Data collection}

In Valle d'Aosta, the municipality of Fontainemore could be chosen to represent the municipalities whose economy depends mainly on agriculture (Francesia, 1997). The village is situated $760 \mathrm{~m}$ a.s.l., but its territory ranges from 680 to $2600 \mathrm{~m}$; according to ISTAT (2000) the grassland covers 1247 ha (39\% of the total area). Three farms out of four carry out livestock activities, mainly with dairy cows.

All the 37 livestock farms operating in Fontainemore in 2006 were contacted for this study: 13 of them were part-time activities without a real agro-environmental interest, whereas 2 only bred goats and sheep; 22 dairy farms were therefore selected for the study, thus covering $90 \%$ of the animals and $80 \%$ of the farmland in the municipality.

The farmers were asked to fill in a questionnaire during direct interviews about the following data concerning different management elements:

- farm characteristics (farm type, farm area, extra-land for manure spreading);

- animal production (livestock rate, live weight for each anim

- al category, animal housing, type of manure produced, manure storage systems);

- crop production and management (crop rotation and yield, crop residue management, organic and mineral fertilization);

- farm inputs (live animals, purchased feed, roughage, litter and mineral fertilizers);

- farm outputs (meat and/or live animals, milk, butter and/or cheese, manure to extra-land).

During the farm visit all the data were collected by: i) direct observations (farm type, housing and manure storage structures, manure type, meadow composition); ii) farm accounts and official databases (products sold and purchased, animal stocks, farm land, milk protein content); iii) each farmer's personal evaluation (live weight, animal diet fertilizer management and hay yields). Desk work was then carried out to cross-verify the data, and to compare all the information collected from the farm accounts and sale receipts, the animal diet, the herd size and the milk performance. The quantities of butter and/or cheese sold were verified according to heads of cattle, milk productivity standards and cheese transformation coefficients (Mathiou, 2006).

As already stated (Grignani and Bassanino, 2000; Mulier et al., 2003; Powell et al., 2006), part of the information supplied by farmers in commercial farming results appears inaccurate, or not known, especially for farm products recycled in animal feeding: further contact with the farmers and their feed consultants was sometimes necessary. When the NP content in some farm products was unknown, it was estimated using standard figures (Table 2). The hay was analysed for each farm

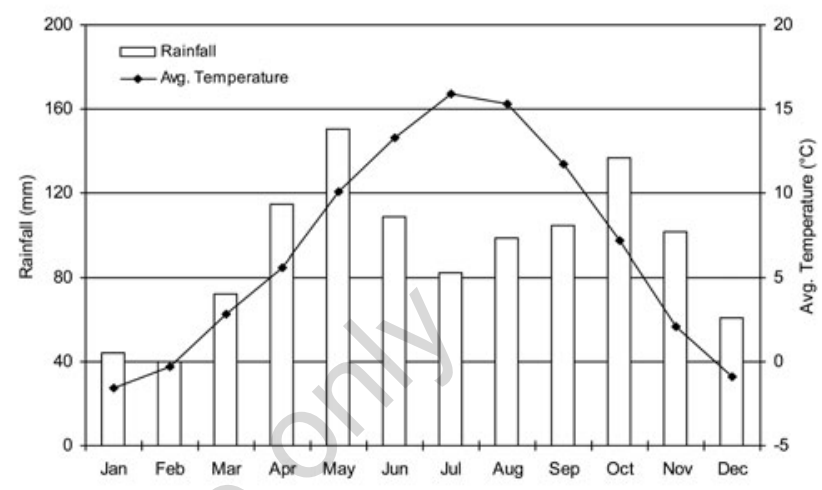

Figure 1. Climatic characteristics in Fontainemore in the Valle d'Aosta Region (Mercalli et al., 2003).

Table 1. Agricultural land use in the municipality of Fontainemore as compared with the Valle d'Aosta region (ISTAT, 2000).

\begin{tabular}{lcccc} 
& \multicolumn{2}{c}{$\begin{array}{c}\text { Fontainemore } \\
\text { (ha) }\end{array}$} & $\begin{array}{c}\text { Valle d'Aosta } \\
\text { (\%) }\end{array}$ & $\begin{array}{c}\text { (ha) } \\
\text { (\%) }\end{array}$ \\
Permanent grassland & 1247 & 39.28 & 69,623 & 21.35 \\
Vineyards and orchards & 3 & 0.10 & 1245 & 0.38 \\
\hline Other crops & 2 & 0.05 & 319 & 0.10 \\
Total UAA & 1252 & 39.45 & 71,187 & 21.83 \\
\hline Total surface & 3174 & 100 & 326,030 & 100 \\
\hline
\end{tabular}

Table 2. Nitrogen-phosphorus content adopted for the main crops and animal products.

\begin{tabular}{|c|c|c|c|c|}
\hline \multicolumn{2}{|l|}{ Feedstuff, \% DM } & $\mathbf{N}$ & $\mathbf{P}$ & Reference \\
\hline Wheat & $\begin{array}{l}\text { Grain } \\
\text { Straw } \\
\text { Bran } \\
\text { Flour }\end{array}$ & $\begin{array}{l}2.3 \\
0.8 \\
2.5 \\
2.4\end{array}$ & $\begin{array}{l}0.4 \\
0.1 \\
1.3 \\
0.7\end{array}$ & $\begin{array}{l}\text { Grignani et al., } 2003 \\
\text { Grignani et al., } 2003 \\
\text { Piccioni, } 1989 \\
\text { Piccioni, } 1989\end{array}$ \\
\hline Maize & $\begin{array}{l}\text { Grain } \\
\text { Residues } \\
\text { Silage } \\
\text { Flour }\end{array}$ & $\begin{array}{l}1.7 \\
0.8 \\
1.2 \\
1.4\end{array}$ & $\begin{array}{l}0.3 \\
0.1 \\
0.2 \\
0.3\end{array}$ & $\begin{array}{l}\text { Grignani et al., } 2003 \\
\text { Grignani et al., } 2003 \\
\text { Grignani et al., } 2003 \\
\text { Piccioni, } 1989\end{array}$ \\
\hline Barley & Grain & 2.1 & 0.3 & Grignani et al., 2003 \\
\hline Permanent meadows & $\begin{array}{l}\text { Hay, } 1^{\text {st }} \text { cut } \\
\text { Hay, } 2^{\text {nd }} \text { cut }\end{array}$ & $\begin{array}{l}2.4 \\
1.9\end{array}$ & $\begin{array}{l}0.3 \\
0.3\end{array}$ & $\begin{array}{l}\text { This study } \\
\text { This study }\end{array}$ \\
\hline \multicolumn{5}{|l|}{ Animal products, \% } \\
\hline Milk & $\begin{array}{l}\text { Dairy } \\
\text { Goat } \\
\text { Beef }\end{array}$ & $\begin{array}{l}0.6 \\
0.6 \\
2.4\end{array}$ & $\begin{array}{l}0.1 \\
0.1 \\
0.9\end{array}$ & $\begin{array}{l}\text { Carnovale and Marletta, } 1997 \\
\text { Carnovale and Marletta, } 1997 \\
\text { Grignani, } 1996\end{array}$ \\
\hline Cheese & $\begin{array}{l}\text { Fontina } \\
\text { Toma }\end{array}$ & $\begin{array}{l}4.3 \\
3.7\end{array}$ & $\begin{array}{l}0.6 \\
0.5\end{array}$ & $\begin{array}{l}\text { Carnovale and Marletta, } 1997 \\
\text { Carnovale and Marletta, } 1997\end{array}$ \\
\hline Butter & & 0.1 & 0.0 & Carnovale and Marletta, 1997 \\
\hline
\end{tabular}

$\mathrm{N}$, nitrogen; P, phosphorus; DM, dry matter. 


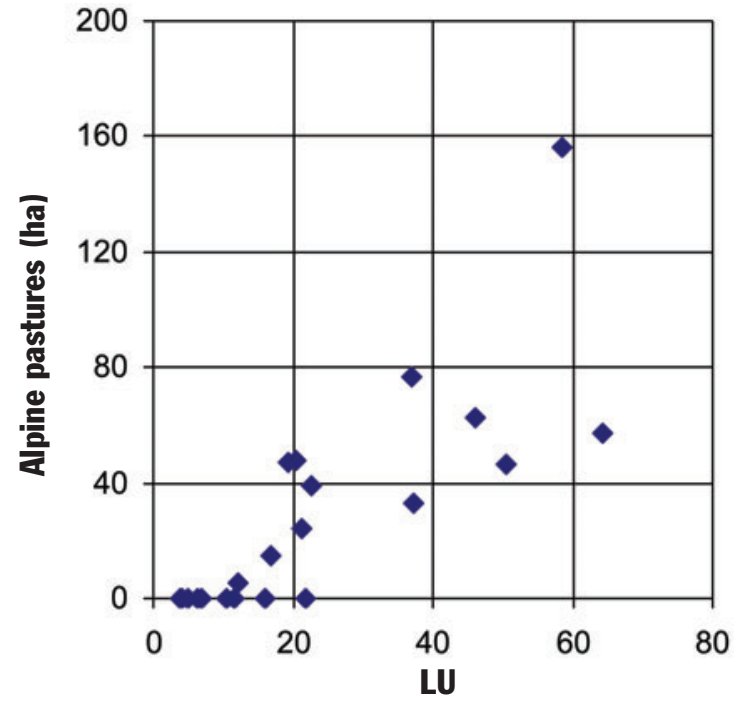

Figure 2. Correlation between alpine pastures and farm stock. Spearman rank correlation $=0.84, P\left(r_{s}\right)=0.000$.

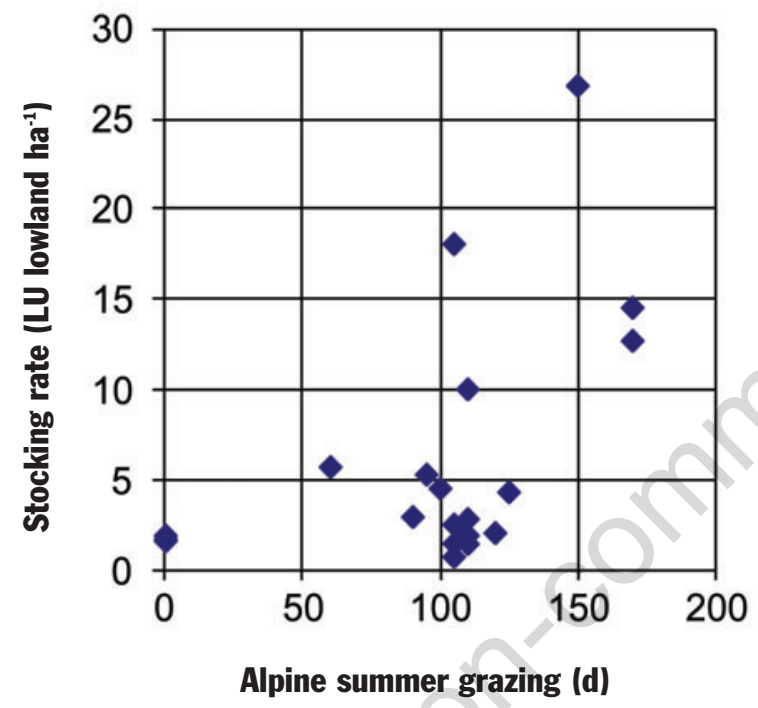

Figure 3. Correlation between duration of alpine summer grazing and stocking rate. Spearman rank correlation $=0.46, P\left(\mathrm{r}_{\mathrm{S}}\right)=0.033$.

for its NP content according to its importance in the animal diet; average data for the chemical composition are reported in Table 2.

We adopted standard data for the atmospheric NP deposition (Mosello et al., 2002), as other authors have done in the past (Domburg et al., 2000; Bassanino et al., 2007). As far as biological N fixation in meadows is concerned, standard coefficients adopted in the Western Alps (Regione Piemonte, 2007) were applied according to the presence of leguminous species, as detected on the fields during farm visits. $\mathrm{N}$ and $\mathrm{P}$ animal excretion in manure were estimated according to the Italian law standard figures (Table 3). Animal heads were transformed into livestock units (LU) according to EUROSTAT (2004) methodology. All the data collected, referring to 2006, the year before the interview, were therefore expressed as N or P fluxes $\left(\mathrm{kg} \mathrm{ha}^{-1} \mathrm{y}^{-1}\right)$. Since the study focuses on lowland farming system management, the summer period $n$ the highland pastures was not considered, as other authors have already done (Penati et al., 2008).

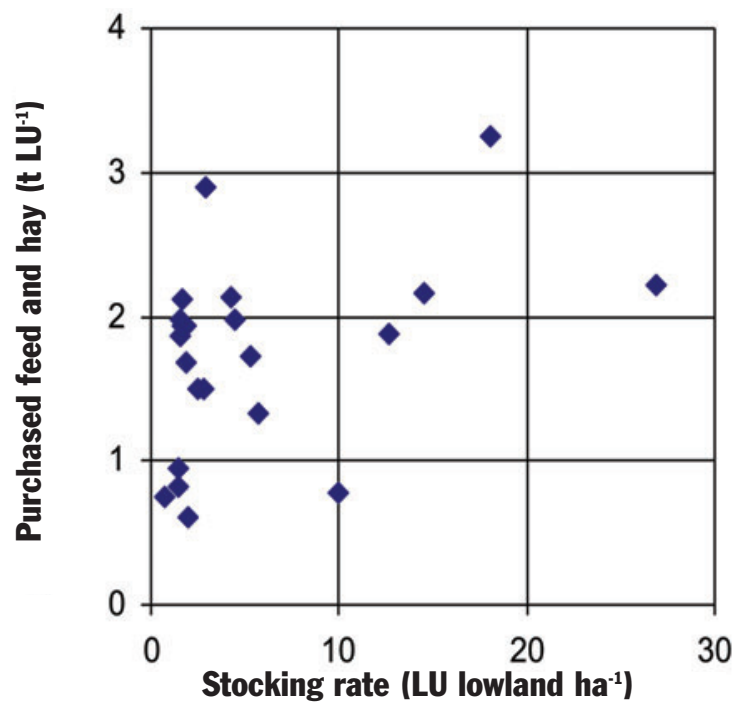

Figure 4. Correlation between stocking rate in lowlands and the purchased feed and hay. Spearman rank correlation $=0.45, \mathrm{P}\left(\mathrm{r}_{\mathrm{s}}\right)=$ 0.037 .

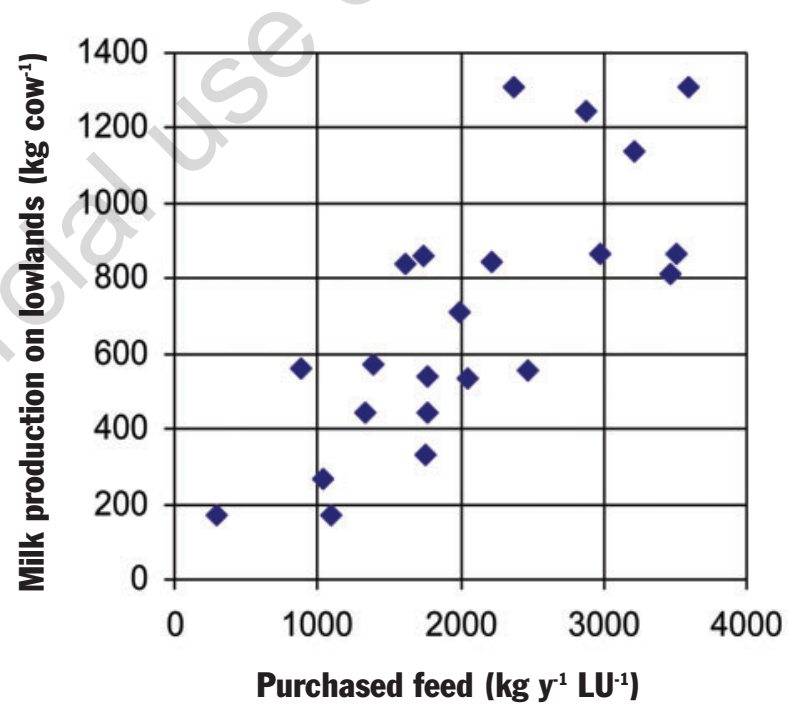

Figure 5. Correlation between milk production obtained in the lowlands and purchased feed. Spearman rank correlation $=0.74$, $\mathbf{P}\left(\mathbf{r}_{\mathrm{S}}\right)=\mathbf{0 . 0 0 0}$.

\section{The farm-gate balance}

The farm-gate balance (FGB) is a useful method when evaluating the agro-environmental sustainability of different farms or farm types (Barry et al., 1993; Grignani and Acutis, 1994; van Faasen and Lebbink, 1994; Weissbach and Ernst, 1994; Giustini et al., 2007). The input data are all the nutrient fluxes that enter the farm, whereas the output data are all the nutrient fluxes that leave the farm.

The FGB adopts all the information available on the farm and, only when this is not sufficient, it refers to bibliographic data. The FGB was calculated here by using the criteria proposed by Simon and Le Corre (1992), as follows:

$$
\begin{aligned}
\mathrm{FGBS}= & \left(\mathrm{Fe}+\mathrm{Ma}_{\text {in }}+\mathrm{Li}+\mathrm{AF}+\mathrm{LA}_{\text {in }}+\mathrm{Bfx}+\mathrm{Ad}\right)- \\
& \left(\mathrm{AP}+\mathrm{CP}+\mathrm{LA}_{\text {out }}+\mathrm{Ma}_{\text {out }}\right)
\end{aligned}
$$

where: $\mathrm{FGBS}=$ farm-gate balance surplus; $\mathrm{Fe}=$ purchased mineral fertilizers; $\mathrm{Ma}=$ manure; $\mathrm{Li}=$ purchased litter; $\mathrm{AF}=$ purchased animal feed 
and forages; $\mathrm{LA}=$ live animals; $\mathrm{BfX}=$ biological $\mathrm{N}$ fixation; $\mathrm{Ad}=$ atmospheric deposition; $\mathrm{AP}=$ animal products sold (dairy products and meat); $\mathrm{CP}=$ crop products sold. Both nitrogen and phosphorus fluxes were analysed. The change in the animal feed and forage stocks during the year taken into account was specifically quantified on each farm. Losses during hay and silage storage were considered negligible. Losses during animal feeding were included in the manure production.

According to Ondersteijn et al. (2002) and Børsting et al. (2003), a nutrient use efficiency coefficient (NUE) was calculated to evaluate the efficient conversion of total inputs into products sold (meat, dairy products and cash crops), as follows:

$$
\mathrm{NUE}_{\text {total }}=\left(\mathrm{AP}+\mathrm{CP}+\mathrm{LA}_{\text {out }}\right) /\left(\mathrm{Fe}+\mathrm{Ma}_{\text {in }}+\mathrm{Li}+\mathrm{AF}+\mathrm{LA}_{\text {in }}+\mathrm{Bfx}+\mathrm{Ad}\right)
$$

The manure output to extra-land was not included in this coefficient, as it cannot be considered an efficient way of exporting nutrients (Kohn et al., 1997; Halberg, 1999).

In order to evaluate the best conversion of the inputs purchased into the products sold, the following indicator was also calculated:

$\mathrm{NUE}_{\text {purchased }}=\left(\mathrm{AP}+\mathrm{CP}+\mathrm{LA}_{\text {out }}\right) /\left(\mathrm{Fe}+\mathrm{Ma}_{\text {in }}+\mathrm{Li}+\mathrm{AF}+\mathrm{LA}_{\text {in }}\right)$

Table 3. Quantity and quality of farm manures produced in a year by each type of animal, according to the Italian law (Italian Regulation, 2006).

\begin{tabular}{|c|c|c|c|c|c|c|}
\hline \multirow[t]{3}{*}{ Animal type } & \multicolumn{2}{|c|}{ Amount $^{\circ}$} & \multicolumn{4}{|c|}{ Excreta } \\
\hline & \multirow{2}{*}{$\begin{array}{l}\text { As manure } \\
\qquad \mathrm{t} \mathrm{lw}^{-1}\end{array}$} & \multirow{2}{*}{$\begin{array}{l}\text { As slurry } \\
\mathrm{m}^{3} \mathrm{t} \mathrm{lw}^{-1}\end{array}$} & \multicolumn{2}{|c|}{ In the manure } & \multicolumn{2}{|c|}{ In the slurry } \\
\hline & & & $\mathrm{kg} \mathrm{N} \mathrm{t} \mathrm{lw}$ & kg P t lw & $\mathrm{kg} \mathrm{N} \mathrm{t} \mathrm{lw}^{-1}$ & $\mathrm{~kg} \mathrm{P} \mathrm{t} \mathrm{lw}^{-1}$ \\
\hline \multicolumn{7}{|l|}{ Cattle } \\
\hline Dairy cows & 26 & 9 & 99 & 25 & 39 & 22 \\
\hline Heifers over 12 months & 22 & 5 & 94 & 26 & 26 & 17 \\
\hline Males 12-18 months & 22 & 5 & 94 & 26 & 26 & 17 \\
\hline Calves 6-12 months & 22 & 5 & 94 & 26 & 26 & 17 \\
\hline Calves $0-6$ months & 22 & 4 & 100 & 26 & 20 & 17 \\
\hline Goats and sheep & 15 & 7 & 55 & 20 & 44 & 16 \\
\hline Horses & 15 & 5 & 48 & 26 & 21 & 26 \\
\hline
\end{tabular}

${ }^{\circ}$ Calves, goats, sheep and horses are housed in bedded boxes, while dairy cows and other cattle are housed in single bedded stalls.

Table 4. Main characteristics of the 22 farms selected.

\begin{tabular}{|c|c|c|c|c|c|c|c|}
\hline Information & & Average & Median & quart. & 3 quart. & Min & $\operatorname{Max}$ \\
\hline Lowland areas & ha & 6.8 & 4.6 & 2.9 & 9.4 & 0.4 & 19.9 \\
\hline Alpine pastures & ha & 27.8 & 10 & 0 & 47.2 & 0 & 156.1 \\
\hline & Days & 88 & 105 & 68 & 110 & 0 & 170 \\
\hline Farm stock & Cow heads & 18 & 15 & 7 & 26 & 3 & 55 \\
\hline & L.U. & 23 & 18 & 8 & 34 & 4 & 64 \\
\hline & L.U./lowland ha & 5.7 & 2.6 & 1.7 & 5.6 & 0.7 & 26.8 \\
\hline Milk & $\mathrm{kg} / \mathrm{L} . U$. & 1744 & 1659 & 1153 & 2316 & 251 & 3511 \\
\hline & $\mathrm{kg} / \mathrm{kg}$ feed & 2.6 & 2.3 & 1.9 & 3.3 & 1.1 & 4.7 \\
\hline Hay & tha & 4.0 & 2.7 & 1.0 & 5.1 & 0.5 & 14.3 \\
\hline & kg/L.U. & 2248 & 1974 & 1629 & 2775 & 786 & 6232 \\
\hline & $\%$ farm hay & 45 & 42 & 18 & 70 & 0 & 93 \\
\hline Feed & $\mathrm{kg} / \mathrm{L} . U$. & 700 & 639 & 466 & 864 & 171 & 1311 \\
\hline Farm manure & $\%$ sold & 34 & 23 & 5 & 57 & 0 & 98 \\
\hline & t/ lowland ha & 24 & 18 & 12 & 28 & 1 & 75 \\
\hline & $\mathrm{kg} \mathrm{N} /$ lowland ha & 129 & 94 & 63 & 151 & 3 & 402 \\
\hline & $\mathrm{kg} \mathrm{P} /$ lowland ha & 25.8 & 18.8 & 12.7 & 29.7 & 0.4 & 79.0 \\
\hline
\end{tabular}

Table 5. Farm-gate balance components ( $\mathrm{kg} \mathrm{N} \mathrm{ha}^{-1}$ of lowland area) of the 22 farms selected.

\begin{tabular}{|c|c|c|c|c|c|c|}
\hline & Average & Median & 1 quart. & 3 quart. & Min & Max \\
\hline Input & 288 & 137 & 103 & 233 & 54 & 1372 \\
\hline Atmospheric deposition & 9 & & & & & \\
\hline Legume fixation & 35 & & & & & \\
\hline Live animals & 4 & 1 & 0 & 6 & 0 & 23 \\
\hline Litter & 11 & 4 & 2 & 15 & 0 & 64 \\
\hline Hay & 116 & 45 & 24 & 99 & 5 & 597 \\
\hline Animal feed & 112 & 48 & 31 & 89 & 4 & 644 \\
\hline Output & 213 & 73 & 30 & 214 & 5 & 1220 \\
\hline Milk/cheese & 48 & 30 & 19 & 46 & 2 & 250 \\
\hline Sold manure & 148 & 41 & 6 & 161 & 0 & 900 \\
\hline Live animals/meat & 16 & 8 & 5 & 17 & 1 & 70 \\
\hline Surplus & 75 & 65 & 50 & 93 & -11 & 226 \\
\hline NUE total & 0.23 & 0.23 & 0.18 & 0.25 & 0.09 & 0.37 \\
\hline $\mathrm{NUE}_{\text {purchased }}$ & 0.36 & 0.32 & 0.29 & 0.42 & 0.14 & 0.67 \\
\hline
\end{tabular}


As already explained, nutrient budgets disregard all data concerning the summer pasture period.

\section{Statistical analysis}

All the variables describing the characteristics of the farms and the different components of the FGB have been analysed in terms of average, median, first and third quartiles, maximum and minimum value. The difference between average and median is index of skewness of the distribution.

The interval of values included in the range $1^{\text {st }}-3^{\text {rd }}$ quartiles contains $50 \%$ of total cases. Correlation between variables has been analysed using non parametric Spearman Rank correlation.

\section{Results}

\section{Farm characteristics}

Table 4 reports the general characteristics of the 22 dairy farms selected, whereas Figures 2, 3, 4 and 5 describe correlations between the main management aspects.

Data are widely spread, because of large differences in farm size and herd management. A large part of the farms has alpine pastures for summer grazing, accounting for an average of 28 ha per farm; however, some farms remain on the lowlands the whole year. Lowland surfaces also show quite a high variability ranging from 0.4 to 19.9 ha, with an average value of $6.8 \mathrm{ha}$. Farm stock size is $23 \mathrm{LU}$ on average per farm but some farms reach very low $(4 \mathrm{LU})$ or high values (64 LU). As reported in Figure 2, herd size is set according to the availability of alpine pastures $\left(\mathrm{r}_{\mathrm{s}}=0.84 ; \mathrm{P}\left(\mathrm{r}_{\mathrm{s}}\right)=0.000\right)$. Consequently an unbalanced stocking rate referred to the lowland is common, showing an average value of $5.7 \mathrm{~L} . \mathrm{U}$. ha ${ }^{-1}$, but reaching a maximum of $26.8 \mathrm{LU} \mathrm{ha}^{-1}$. As shown in Figure 3, the high stocking rate in lowlands is also related to the period during which animals stay on alpine pastures $\left(r_{s}=0.46\right.$; $\left.\mathrm{P}\left(\mathrm{r}_{\mathrm{s}}\right)=0.033\right)$. Farmers that move the herd to the alps earlier and can leave it out on the pastures for a longer period, can breed more animals because of greater forage availability, thus increasing the stocking rate in the lowlands during the winter period.

During the lowland season, farms have to buy hay (only $45 \%$ is produced on average on the farm) and feed (700 kg per LU per year, ranging from 170 to 1300), as already detected by Corti et al. (2005) in similar conditions. Figure 4 shows the relation $\left(r_{s}=0.45 ; P\left(r_{s}\right)=0.037\right)$ between stocking rate and the total amount of purchased feedstuff. However, data are affected by the length of the alpine pasture period and different hay production, ranging from 0.5 to $14.3 \mathrm{t} \mathrm{ha}^{-1}$ and with an average of $4.0 \mathrm{t} \mathrm{ha}^{-1}$. Grasslands are usually not irrigated and, are often only cut once a year depending on the field slope.

Milk production during the lowland period is around $1700 \mathrm{~kg}$ per LU per year, but some farms could reach $3500 \mathrm{~kg}$ per $\mathrm{LU}$, thanks to more selected animals and a larger feeding supply $\left(\mathrm{r}_{\mathrm{s}}=0.74 ; \mathrm{P}\left(\mathrm{r}_{\mathrm{s}}\right)=0.000\right)$

Table 6. Farm-gate balance components ( $\mathrm{kg} \mathrm{P} \mathrm{ha-1} \mathrm{of} \mathrm{lowland} \mathrm{area)} \mathrm{of}$ the 22 farms selected.

\begin{tabular}{lcccccc} 
& Average & Median & 1 quart. 3 quart. Min Max \\
Input & 50 & 25 & 13 & 41 & 3 & 254 \\
$\quad$ Live animals & 1 & 0 & 0 & 2 & 0 & 8 \\
Litter & 1 & 0 & 0 & 1 & 0 & 6 \\
Hay & 18 & 7 & 3 & 15 & 1 & 90 \\
Animal feed & 29 & 16 & 9 & 26 & 1 & 152 \\
Output & 44 & 15 & 7 & 43 & 1 & 249 \\
$\quad$ Milk/cheese & 8 & 5 & 3 & 8 & 0 & 44 \\
Sold manure & 30 & 8 & 1 & 32 & 0 & 180 \\
Live animals/meat & 6 & 3 & 2 & 6 & 0 & 25 \\
\hline Surplus & 6 & 5 & -2 & 14 & -10 & 27 \\
NUE total & 0.34 & 0.31 & 0.25 & 0.42 & 0.17 & 0.59
\end{tabular}

Table 7. Nitrogen and phosphorus farm-gate surpluses on bovine farms under different management conditions.

\begin{tabular}{|c|c|c|c|c|}
\hline Farm type & Region & $\mathbf{N}$ & $\mathbf{P}$ & Reference \\
\hline Intensive dairy cows & Piedmont, Italy & $308^{\circ}$ & 76 & Grignani, 1996 \\
\hline Suckling cows & Piedmont, Italy & $114^{\circ}$ & 34 & Grignani, 1996 \\
\hline Dairy cows & Piedmont, Italy & 318 & n.a & Bassanino et al., 2007 \\
\hline Suckling cows & Piedmont, Italy & 100 & n.a & Bassanino et al., 2007 \\
\hline Dairy cows, Alps & Lombardy, Italy & 182 & 28 & Penati et al., 2008 \\
\hline Intensive dairy cows & Emilia Romagna, Italy & 300 & n.a & De Roest, 2000 \\
\hline Parmigiano Reggiano dairy cows & Emilia Romagna, Italy & 231 & n.a & De Roest, 2000 \\
\hline Dairy cows, lowland & Tuscany, Italy & $136^{\circ}$ & 73 & Giustini et al., 2007 \\
\hline Dairy cows, uplands & Tuscany, Italy & $53^{\circ}$ & 27 & Giustini et al., 2007 \\
\hline Dairy cows & Brittany, France & $206^{\circ}$ & n.a & Simon et al., 1997 \\
\hline Dairy cows & Normandy, France & $128^{\circ}$ & n.a & Simon et al., 1997 \\
\hline Dairy cows, Alps & Switzerland & 41 & 0 & Jeangros and Troxler, 2006 \\
\hline Dairy cows & Flanders, Belgium & 238 & n.a & Nevens et al., 2006 \\
\hline Intensive dairy cows & Allgäu, Germany & $80^{\circ}$ & n.a & Haas et al., 2001 \\
\hline Extensive dairy cows & Allgäu, Germany & $31^{\circ}$ & n.a & Haas et al., 2001 \\
\hline Medium intensive dairy cows & Northwest, Portugal & 413 & 31 & Fangueiro et al., 2008 \\
\hline Intensive dairy cows & Northwest, Portugal & 548 & 44 & Fangueiro et al., 2008 \\
\hline Very intensive dairy cows & Northwest, Portugal & 609 & 38 & Fangueiro et al., 2008 \\
\hline Dairy cows & Scotland, UK & 173 & 30 & Domburg et al., 2000 \\
\hline Dairy cows & Idaho, USA & $314^{\circ}$ & 29 & Hristov et al., 2006 \\
\hline
\end{tabular}

$\mathrm{N}$, nitrogen; P, phosphorus; ${ }^{\circ}$ not accounting for atmospheric depositions; n.a., not available. 
(Figure 5). For these reasons, the feed efficiency varies from 1.1 to 4.7 kg milk per kg feed, depending on the farm feeding strategy. Because lowland areas are limited in size, $34 \%$ of farm manure is sold, on average, outside the farm, usually to orchard or cereal stockless farms situated on the plain in Piedmont, but this number ranges from 0 to $98 \%$.

Manure management and fertilisation of the grasslands are largely affected by the geomorphologic characteristics of the territory. Distribution of the manure is performed manually in many cases, and consequently little manure is spread. Therefore grasslands are often under fertilised, and receive $129 \mathrm{~kg} \mathrm{~N}$ and $26 \mathrm{~kg} \mathrm{P}$ on average per ha.

\section{Farm-gate balances}

As far as $\mathrm{N}$ is concerned, the average data and the quartiles for all the farm-gate balance components and the FGBS are shown in Table 5. The average values largely differ from the median because of very positively skewed values. The average total input is equal to $288 \mathrm{~kg} \mathrm{~N} \mathrm{ha}^{-1}$ but half of the farms show values within the $103-233 \mathrm{~kg} \mathrm{~N} \mathrm{ha}^{-1}$ range. The two main input components are represented by purchased hay and feed, both also having the highest variability. These differences between the farms are due to very high amounts of animal feed and hay bought in some very intensive farms (up to $600 \mathrm{~kg} \mathrm{~N} \mathrm{ha}^{-1}$ for both inputs) that rely on a very large amount of purchased animal feeding. Live animals and litter show a relatively small value, if compared to imported hay and feed, and also have reduced variability.

Output shows a positively skewed distribution as well. The average is equal to $213 \mathrm{~kg} \mathrm{~N} \mathrm{ha}^{-1}$ but half of the farms show values within the $30-214 \mathrm{~kg} \mathrm{~N} \mathrm{ha}^{-1}$ range. The output data also differ substantially between farms. The manure sold represents $70 \%$ of the total output on average and is also the component which differentiates the farms most. The FGBS is equal to $75 \mathrm{~kg} \mathrm{~N} \mathrm{ha}^{-1}$ on average, with smaller data variation. As far as $\mathrm{P}$ is concerned, the data for all the farm-gate balance components and the FGBS are shown in Table 6. Reported values show the same considerations already expressed in relation to the $\mathrm{N}$ FGB. The FGBS is equal to $6 \mathrm{~kg} \mathrm{P} \mathrm{ha}^{-1}$ in this case, but more than $25 \%$ of the farms considered show a negative value.

The $\mathrm{N}$ and P FGBS presented in this work are compared to others calculated for bovine farms under different management and environmental conditions in Italy and Europe (Table 7). In general our data can be compared with the lower values of the distribution and they are similar to those measured on mountains or other extensive environments. The situation does not change even if the $3^{\text {rd }}$ quartile of the distribution is taken into account.

\section{Discussion}

Dairy farms in Valle d'Aosta aim at producing typical cheeses, in accordance with the regional market strategy. Typical cheeses are mainly produced on the alpine pastures because of the higher potential production and the grants that farmers receive from the Rural Development Programme. It is for this reason that farms are characterised by a herd size set on the basis of the availability of pastures. The herd is kept in lowland areas from the autumn to the spring and consequently their agronomical management is often disregarded. This farm area is not planned correctly and leads to a high stocking rate. During the lowland period large amounts of feedstuff are imported onto the farms, as farm productions are too low to satisfy the herd needs. Grassland production results as being quite low: the first cut is usually in June, when climatic conditions do not allow a high quality product. Moreover the following cuts are often disregarded because of under fertilisation, lack of irrigation and lack of manpower during the summer. The high stocking rate in the lowlands does not facilitate farm self-sufficiency in forages.

However, large surpluses are reported only in a limited number of cases as large amounts of manure are exported to other farms and other regions. This kind of manure management is driven by the geomorphologic condition of the territory, which limits the mechanisation of manure spreading. The FGBS found in this work are quite low in comparison to the European and Italian dataset reported in Table 7, even if only data from similar mountain environments is considered. These results mask an environmental unbalance, but the limiting factors conditioning the farm management also limit the possibility of improving fertilisation plans.

\section{Conclusion}

The possibility of realizing adequate income from quality cheese production, together with the grants obtained from the Rural Development Programme, leads farmers to design their stocking farms depending on the availability of Alpine pastures, in terms of both surface and grazing period. This results in good management and an effective preservation of the Alpine landscape. However, there are negative consequences in the lowland areas, where the very low availability of pastures can induce agro-environmental problems caused by the high stocking rate, even though they are only concentrated in some months. The municipality of Fontainemore is an example of this situation: a very low nutrient use efficiency is evident here.

According to the results of this study, the agro-environmental sustainability of the lowland areas should be taken into account more, consequently management of the winter stocking rate and fertilisation of lowland meadows and pastures would be improved. This could be done, for example, by enhancing the value of the lowland products, thus increasing the quality and the multifunctionality of the lowland areas.

\section{References}

Association Régionale Éleveurs Valdôtains, 2009. Assemblea ordinaria dei soci. Vallée d'Aoste Élevage, No. 27, pp 4-9, Available from: http://www.arev.it/allevatori/allegati/Elevage_27_688.pdf

Barry D.A.J., Goorahoo D., Goss M.J., 1993. Estimation of nitrate concentrations in groundwater using a whole farm nitrogen budget. J. Environ. Qual 4:767-775.

Bassanino M., Grignani C., Sacco D., Allisiardi E., 2007. Nitrogen balances at the crop and farm-gate scale in livestock farms in Italy. Agr. Ecosys. Environ. 122:282-294.

Børsting C.F., Kristensen T., Misciattelli L., Hvelplund T., Weisbjerg M.R., 2003. Reducing nitrogen surplus from dairy farms. Effects of feeding and management. Livest. Prod. Sci. 83:165-178.

Carnovale E., Marletta, L., 1997. Tabelle di composizione degli alimenti. Ist. Naz. Nutrizione, EDRA Ed., Milano, Italy.

Cavallero A., Bassignana M., Iuliano G., Reyner, A., 1997. Sistemi foraggeri semi-intensivi e pastorali per l'Italia settentrionale: analisi di risultanze sperimentali e dello stato attuale dell'alpicoltura. Riv. Agron. 31:482-504.

Corti M., de Ros G., Bianchi, M.C., 2005. Un sistema zootecnico di una valle prealpina e le sue prospettive alla luce di criteri di sostenibilità: il caso della Val Taleggio. Quaderno SOZO0ALP 2:130-139.

de Roest K., 2000. Interrelationships between nitrogen balances and technical and structural characteristics of dairy farms in Northern Italy. pp 177-192 in: B.P. Weidema and M.J.G. Meeusen (eds.) Agricultural data for Life Cycle Assessments, Report 2.00.01 Volume 1, LEI Ed., The Hague, The Netherlands. 
sis of nitrogen losses from dairy farms. J. Environ. Manage. 50:417428.

Mantovani R., Bailoni L., Chatel A., Bassignana M., 2003. Relationship between pasture and nutritional aspects of Fontina cheese manufactured in alpine farms. Ital. J. Anim. Sci. 2:287-289.

Mathiou F., 2006. La Fontina - dove e come nasce. Cooperativa Produttori Latte e Fontina Ed., Saint-Christophe, A0, Italy.

Mercalli L., Cat Berro D., Montuschi S., Castellano C., Ratti M., Di Napoli G., Mortara G., Guindani N., 2003. Atlante Climatico della Valle d'Aosta. Società Meteorologica Subalpina Ed., Bussoleno, TO, Italy.

Mosello R., Brizzio M.C., Kotzias D., Marchetto A., Rembges D., Tartari G., 2002. The chemistry of atmospheric deposition in Italy in the framework of the National Programme for Forest Ecosystem Control (CONECOFOR). J. Limnol. 61:77-92.

Mulie, A., Hofman G., Baecke E., Carlier L., de Brabander D., de Groote G., de Wilde R., Fiems L., Janssen G., van Cleemput 0., van Herck A., van Huylenbroeck G., Verbruggen I., 2003. A methodology for the calculation of farm level nitrogen and phosphorus balances in Flemish agriculture. Eur. J. Agron. 20:45-51.

Nevens F., Verbruggen I., Reheul D., Hofman G., 2006. Farm gate nitrogen surpluses and nitrogen use efficiency of specialized dairy farms in Flanders: Evolution and future goals. Agr. Syst. 88:142-155.

Ondersteijn C.J.M., Beldman A.C.G., Daatselaar C.H.G., Giesen G.W.J., Huirne R.B.M., 2002. The Dutch Mineral Accounting System and the European Nitrate Directive: implications for N and P management and farm performance. Agr. Ecosys. Environ. 92:283-296.

Penati C., Sandrucci A., Tamburini A., Bava L., Timini M., 2008. Bilanci aziendali dell'azoto e del fosforo di un campione di allevamenti bovini della bassa Valtellina e Valchiavenna. Quaderni S0Z00ALP 5:226-236.

Piccioni M., 1989. Dizionario degli alimenti per il bestiame. Edagricole Ed., Bologna, Italy.

Powell J.M., Jackson-Smith D.B., McCrory D.F., Saam H., Mariola M., 2006. Validation of feed and manure data collected on Wisconsin dairy farms. J. Dairy Sci. 89:2268-2278.

Regione Piemonte, 2007. Regolamento regionale recante: Disciplina generale dell'utilizzazione agronomica degli effluenti zootecnici e delle acque reflue e programma di azione per le zone vulnerabili da nitrati di origine agricola (Legge regionale 29 dicembre 2000, $n$. 61). D.P.G.R. 29/10/2007 n¹0/R., B.U. 31 ottobre 2007, n. 44.

Roumet J.P., Pauthenet Y., Fleury P., 1999. Tipologia dei prati permanenti della Valle d'Aosta. Institut Agricole Régional Publ., Aosta, Italy.

Simon J.C., Le Corre L., 1992. Le bilan apparent de l'azote à l'échelle de l'exploitation agricole: methodologie, exemples de résultats. Fourrages 129:79-94.

Simon J.C., Vertès F., Decau M.L., Le Corre L., 1997. Les fluxes d'azote au pâturage. I - Bilans à l'exploitation et lessivage du nitrate sous prairies. Fourrages 151.249-262.

Trione S., 2005. L'equilibrio economico del sistema latte bovino in Valle d'Aosta. INEA Publ., Roma, Italy

van Faasen H.G., Lebbink G., 1994. Organic matter and nitrogen dynamics in conventional versus integrated arable farms. Agr. Ecosys. Environ. 51:209-226.

Weissbach F., Ernst P., 1994. Nutrients budgets in farm management to reduce nutrient emissions. In: L. 't Mannetje and J. Frame (eds.) Grassland and society. pp 343-360 in Proc. 15th Meet. Eur. Grassland Federation, Wageningen, The Netherlands. 